\title{
PENGARUH PERILAKU BERLALU LINTAS TERHADAP EFEKTIVITAS VIDEOTRON
}

\author{
Fentisari Desti Sucipto \\ Universitas Negeri Malang \\ piknos.design@gmail.com
}

\begin{abstract}
Abstrak
Videotron merupakan salah satu media periklanan yang merupakan pengembangan dari billboard (papan reklame) dengan menggunakan teknik gambar bergerak untuk menampilkan iklan kepada khalayak. Videotron sengaja diletakkan pada pemberhentian rambu apill agar dapat terlihat secara langsung oleh para pengendara yang berhenti. Peletakan videotron di tiap arah pemberhentian lampu apill yang berbeda tentu berdampak pada perilaku pengendara dalam berlalu lintas. Penelitian ini bertujuan untuk mengetahui dampak penempatan videotron terhadap perilaku berlalu lintas yang mengacu pada prinsip pengamatan nonparticipant observation dan participant observation. Teknik analisis data menggunakan sistem coding (pengkodean), dengan memperhatikan faktor atensi pengendara terhadap rambu apill.
\end{abstract}

Kata Kunci: videotron, penempatan videotron, perilaku berlalu lintas, atensi, perilaku

\begin{abstract}
Videotron is one of the advertisement media basicly development from billboard using image moving technique or motion. The purpose is for showing the advertisement for public. Videotron deliberate places in the four junction near by aphill traffic sign, thus videotron can be seen directly by the rider who stop because of the traffic light. The different videotron placing in every direction impacts on driver traffic behaviour. This is research investigated the impacts of traffic behaviour which refers to non participant observation and participant observation principal. The data analysis used coding which consider the attention factor of driver to the aphill traffic.
\end{abstract}

Keyword : videotron, videotron placing, traffic behaviour, attention, behaviour

\section{Pendahuluan}

Videotron merupakan salah satu media periklanan yang merupakan pengembangan dari billboard (papan reklame). Berbeda dengan billboard yang memanfaatkan proses cetak untuk menampilkan iklan, videotron menggunakan teknik gambar bergerak untuk menampilkan iklan kepada khalayak. 
Jurnal Use and Effectiveness of Billboards (2006) melakukan survei pada 1.315 perusahaan yang pernah beriklan di billboard. Hasil penelitian ini menunjukkan bahwa alasan perusahaan yang beriklan di billboard antara lain adalah keterjangkauan jarak pandang (visibility) yang tinggi terhadap audience , mudah dilihat, mempunyai kesan yang kuat serta dapat dilihat 24 jam sehari.

Menurut Kasali (1992) , media pada iklan luar ruang (outdoor advertising) wajib memiliki beberapa kriteria antara lain : mudah dibaca, pesan yang singkat, ditampilkan secara jelas dan dapat dibaca setidaknya dalam waktu tujuh detik. Ketentuan yang dimaksudkan oleh Kasali adalah ketentuan untuk reklame.

Rustan (2009) membuat sebuah acuan jarak pandang normal untuk menjagkau pandangan audience. Berikut ilustrasinya,

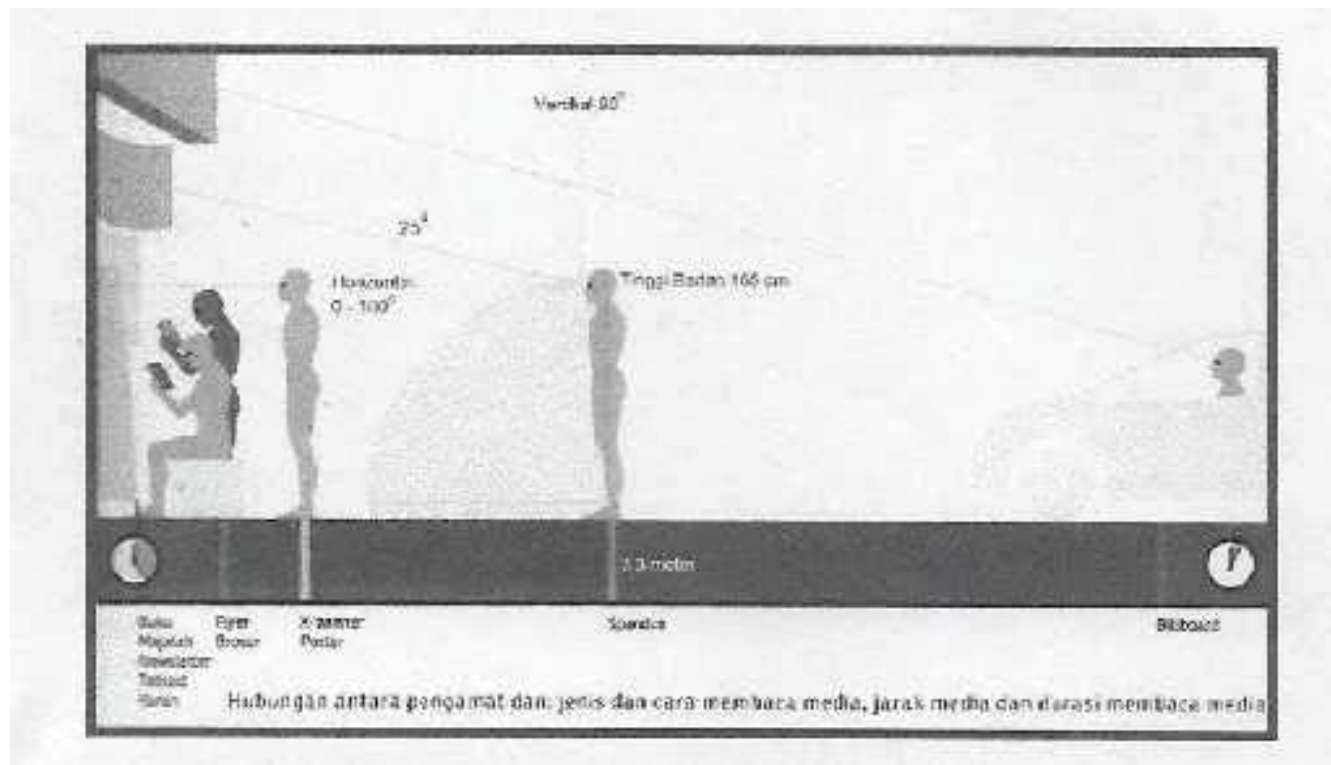

Gambar 1 : Hasil Scan Rustan (2009)

Penelitian berjudul The Impact of modern traffic and traditional traffic rules of Yogyakarta yang dilakukan oleh Lorenz (2002) melalui metode pengamatan nonparticipant menghasilkan data mengenai hierarki kendaraan di jalan raya dan juga komunikasi yang terjadi di jalan. Komunikasi yang terjalin antara lain, pengendara dapat memprediksi perpindahan dari pengguna jalan lain. Hal ini, merupakan jenis komunikasi nonverbal yang terjadi tanpa disadari pengendara. Cara seorang pengendara memprediksi tersebut dapat dilihat dari lampu sein, kecepatan, klakson dan berbagai atribut kendaraan lainnya yang dapat digunakan. Dimanapun kita berada tidak hanya di Yogyakarta, kita juga dapat melihat pola yang sama di jalan. Karena para pengendara memanfaatkan sistem yang sudah ada di kendaraannya masing-masing. Tentu saja, hal ini erat kaitannya dengan sistem visual dari seseorang.

Dalam penelitian lain di dunia kesehatan, terdapat beberapa metode untuk mengukur pergerakan visual mata ketika berkendara. Salah satunya adalah dengan oculometry . Dalam penelitian berjudul Journal application of eye-tracking in drivers 
testing: a review of research (2015), jika mata memandang sejauh lebih dari enam meter, maka kedudukan mata akan sejajar. Namun, jika mata memandang sesuatu yang jaraknya kurang dari satu meter, maka kedua mata akan konvergen. Pergerakan mata saat mengendara juga meningkat saat melihat pergerakan dari kendaraan lainnya yang sedang melaju. Ini berarti, bahwa saat pengendara di jalan, mereka mengalami distorsi visual (pengelihatan) dari kendaraan bergerak lainnya. Jika dimaknai lebih jauh, maka setiap orang lebih mudah terdistorsi pengelihatannya pada benda - benda yang bergerak, daripada benda-benda yang diam.

Pemaparan di atas berhubungan dengan hasil penelitian Duchowski (2002) yang berjudul A breadht-first survey of eye tracking application. Dalam penelitiannya, selama berkendara saat siang hari, cukup banyak visual distraction (pengalih pandangan) seperti billboard yang dipasang di tepi jalan raya. Namun, ketika malam hari, hal ini jadi berkurang. Penelitian ini, merupakan penelitian yang cukup detail pengumpulan datanya. Karena penelitian ini berhasil sampai pada kesimpulan bahwa saat seseorang berkendara, maka pandangannya juga akan terganggu oleh billboard yang dipasang di tepi jalan. Lebih jauh lagi, pandangan erat kaitannya dengan sesuatu yang menarik perhatian (atensi). Saat seseorang tertarik akan sesuatu, maka pandangannya akan menuju kepada hal tersebut. Namun, penelitian Duchowski (2002) di atas hanya membahas seputar billboard yang dicetak. Sedangkan, perkembangan saat ini, terdapat digital billboard dimana adanya teknologi LED yang mendukung sebuah tampilan dari billboard terlebih lagi untuk videotron.

Dari segi spasial, banyak videotron ditempatkan di area perempatan, yang merupakan tempat berhenti sesaat bagi pengendara. Perempatan juga merupakan titik bertemunya kendaraan dari beberapa arus yang berbeda. Hal ini menjadi keuntungan tersendiri bagi penempatan videotron, karena akan semakin banyak pengendara yang merespon iklan pada videotron tersebut. Namun, tidak semua perempatan yang terdapat videotron dilewati oleh empat tipe arus lalu lintas. Seperti pada perempatan yang ada di Jalan Urip Sumoharjo Yogyakarta (depan Mall Galeria), yang hanya dilewati oleh dua arus saja. Lalu pada perempatan nol kilometer Yogyakarta yang dilewati oleh tiga arus. Dan pada kedua perempatan tersebut terdapat videotron yang diletakkan pada sisi yang menghadap langsung dengan berhentinya pengendara saat lampu merah.

Berdasarkan pemaparan di atas, salah satu alasan mengapa videotron diletakkan pada perempatan adalah agar terlihat secara langsung oleh para pengendara yang berhenti. Namun, bagaimana dampak dan keefektifan dari penempatan tersebut bagi pengendara merupakan persoalan evaluasi. Terutama, jika pada perempatan tersebut bukan merupakan perempatan yang mencangkup empat arah. Persoalan inilah yang belum diketahui secara detail oleh ilmu pengetahuan desain.

Shinar (2007) telah melakukan sebuah penelitian mengenai digital billboard. Dalam hal ini videotron adalah salah satu dari digital billboard yang dimaksud oleh Shinar. Shinar menemukan bahwa 23\% para pengendara menoleh ke arah kanan yang merupakan arah dimana billboard tersebut diletakkan. Tetapi hanya $10 \%$ dari pengendara yang menoleh ke arah dimana billboard tersebut tidak terlihat oleh mereka. Di samping itu, banyak penelitian yang telah meneliti dampak dari digital billboard terhadap pengendara, saat mereka berkendara. Menurut Shinar (2007) perlu diadakannya 
sebuah penelitian yang akan menghasilkan data mengenai dampak dari digital billboard terhadap pengendara saat mereka mempunyai waktu luang lebih banyak di sela-sela mereka mengendara. Salah satu cara untuk meneliti hal yang peneliti dalam penulisan ini akan mencoba untuk mengamati dampak penempatan videotron terhadap perilaku berlalu lintas. Pertanyaan penelitian yang diajukan oleh peneliti adalah bagaimana dampak penempatan videotron terhadap perilaku berlalu lintas?

\section{Metode Penelitian}

\section{Pengumpulan Data}

Metode pengumpulan data yang digunakan secara umum mengacu pada prinsip pengamatan nonparticipant observation dan participant observation. Peneliti melakukan nonparticipant observation karena objek yang diamati oleh peneliti merupakan perilaku dan perilaku merupakan hal yang terjadi secara naturalistik. Ostrower (1998) nonparticipant observation mengarah pada pengamatan tidak terlibat dimana peneliti tidak menjadi bagian atau anggota dari subjek yang diteliti. Hal ini baik dilakukan untuk peneliti yang ingin melihat suatu fenomena secara ethic sehingga data yang diperoleh natural. Peneliti juga melakukan participant observationt karena peneliti mengamati fenomena dari sudut pandang emic. Menurut Fetterman (2010) , sudut pandang ini menjadi dasar untuk penelitian kualitaif karena peneliti dapat memahami apa yang dirasakan oleh subyek penelitian.

\section{Alasan Pemilihan Kasus}

Kasus yang dipilih pada pengamatan ini adalah dampak penempatan videotron pada perempatan terhadap perilaku berlalu lintas. Hal ini dianggap menarik karena videotron adalah bagian dari dunia periklanan. Dunia periklanan merupakan dunia yang dekat dengan keilmuan pengamat. Sedangkan mengamati perilaku berlalu lintas terhadap videotron adalah salah satu cara untuk mengukur reaksi terhadap videotron. Reaksi ini yang nantinya akan menentukan apakah videotron tersebut efektif atau tidak terhadap pelaku berlalu lintas. Karena, pelaku berlalu lintas adalah target audience dari pemasangan videotron di sekitar jalan raya.

Pelaku berlalu lintas dalam hal ini hanya dibatasi pada pengendara sepeda motor dan orang yang dibonceng dibelakangnya. Hal yang mendasari pemilihan ini, karena diantara pengendara lain seperti mobil, truk maupun bis, pengendara motor adalah pengendara yang paling mudah untuk diamati reaksinya. Karena tidak tertutup oleh kaca kendaraan, seperti halnya mobil dan bus. Selain itu, pengendara motor juga mendominasi kendaraan di jalan raya. Sehingga, data yang akan didapatkan akan beragam.

\section{Alasan pemilihan tempat dan waktu penelitian}

Pemilihan lokasi yaitu di perempatan yang terdapat videotron. Dua lokasi yang dipilih yaitu Perempatan Malioboro di titik nol kilometer dan videotron Mall Galeria di perempatan Urip Sumoharjo. Perempatan Mall Galeria dipilih dikarenakan Mall ini 
memiliki dua jalur dua arah dan dua jalur searah. Pada perempatan ini, terdapat satu jalur searah dan satu jalur dua arah yang dapat melihat secara langsung menghadap ke videotron ketika lampu merah menyala. Sedangkan untuk perbandingan berdasarkan penempatan, maka dipilih Perempatan Malioboro karena perempatan ini terdapat satu jalur searah yang menghadap langsung kepada videotron dan tiga jalurnya dua arah.

Waktu yang tepat mengamati adalah ketika banyak kendaraan berlalu lintas sekitar area tersebut. Sehingga, pengamatan yang dilakukan di perempatan Malioboro adalah pada pukul 07.00 - 09.00 saat jam berangkat sekolah dan berangkat bekerja. Tetapi, di perempatan Mall Galeria dilakukan pada jam 11.00 - 13.00 saat jam pulang sekolah atau jam istirahat kantor. Hal ini mengacu pada meningkatnya arus kendaraan pada setiap masing-masing perempatan yang berbeda. Sehingga durasi setiap satu kali pengamatan adalah dua jam.

\section{Metode Pengamatan}

Dalam pengamatan ini, metode yang digunakan adalah pengamatan terlibat dan tidak terlibat. Pengamatan terlibat dilakukan peneliti adalah terlibat sebagai pengguna lalu lintas. Tujuannya, agar peneliti memahami sudut pandang saat berkendara serta jarak pandang pengendara saat berhenti di perempatan. Caranya adalah peneliti mengendarai motor sebagai pengemudi dan sebagai orang yang dibonceng.

Sedangkan pengamatan tidak terlibat yang dilakukan oleh peneliti, bertujuan untuk memahami fenomena perilaku berlalu lintas saat berhenti di perempatan lampu merah yang menghadap ke arah videotron secara langsung. Pada saat melakukan pengamatan tidak terlibat, peneliti memposisikan diri di berbagai posisi di pinggir perempatan tersebut untuk mendapatkan hasil yang maksimal.

Dalam pengamatan tidak terlibat, untuk mengefektifkan pengamatan, peneliti membuat panduan pengamatan berupa tabel sebagai berikut:

\begin{tabular}{|l|l|l|l|l|l|}
\hline No. & Perempatan & Pukul & Arah & Aspek yang diamati & Hasil pengamatan \\
\hline 1 & Mall Galeria & & & & \\
\hline 2 & 0 Kilometer & & & & \\
\hline
\end{tabular}

Ada dua lokasi perempatan yang telah diamati oleh peneliti yaitu perempatan mall Galeria dan perempatan di nol kilometer. Alasan pemilihan lokasi sudah disebutkan sebelumnya. Kolom pukul akan diisi dengan waktu pelaksanaan pengamatan. Kolom arah akan diisi dengan dari mana arah kendaraan tersebut melaju sebelum menuju perempatan. Aspek yang diamati akan dibedakan menjadi dua hal yaitu pengendara motor yang berperan sebagai pembonceng dan orang yang dibonceng. Terakhir, pada kolom hasil pengamatan, akan dituliskan hasil pengamatan sesuai yang ada di perempatan.

Meskipun, sudah ada tabel seperti di atas, untuk memperdalam pengamatan, peneliti juga melakukan pengukuran terhadap videotron dan rambu apill. Karena hal ini akan berpengaruh pada jarak pandang pengendara.

\section{Teknik Pengamatan}


Peneliti melakukan pengamatan sebanyak enam kali dalam rangka memperoleh hasil untuk dampak penempatan videotron terhadap perilaku berlalu lintas. Empat pengamatan tersebut dilakukan diperempatan Mall Galeria. Sedangkan dua pengamatan lainnya dilakukan di perempatan nol kilometer. Pengamatan dibagi menjadi dua jenis yaitu pengamatan langsung artinya pengamat mengamati langsung di perempatan dan mencatat hasilnya secara manual. Kedua adalah pengamatan melalui rekaman atau tidak langsung yaitu pengamat memutar kembali rekaman video mengenai perilaku para pengendara dan mencatat hasilnya secara detail. Pengamatan melalui video dilakukan oleh peneliti karena, setiap detail kecil dari perilaku yang mungkin terlewat saat pengamatan langsung, akan bisa terlihat pada pengamatan melalui video ini.

Pengamatan dilakukan saat lampu merah pada salah satu perempatan yang diteliti menyala. Hal ini dikarenakan, fokus pada pengamatan ini adalah para pelaku berlalu lintas yang sedang berhenti di perempatan karena lampu merah. Peneliti mencari ruang yang bisa digunakan untuk duduk dan dapat melihat dengan jelas secara mendetail hal hal apa saja yang dilakukan oleh para pengendara motor.

Peneliti memutuskan untuk berhenti melakukan penelitian pada saat peneliti melakukan pengamatan langsung dan tidak langsung yang keenam kalinya. Hal ini dikarenakan informasi yang ditemukan oleh peneliti telah mencapai titik jenuh. Meskipun pelaku dari pengendara berbeda-beda, namun pola perilakunya serupa.

\section{Teknik perekaman}

Alat perekam yang digunakan dalam pengamatan ini berupa video melalui handycam. Hal ini bertujuan untuk memudahkan peneliti meninjau kembali pengamatan lapangan secara lebih mendetail. Karena perilaku yang diamati oleh peneliti berlangsung sangat singkat dengan durasi 40 detik hingga 100 detik , setiap kali lampu merah menyala. Selain itu, resolusi yang digunakan 720 X 576. Resolusi ini cukup untuk melihat secara lebih jelas melalui laptop. Meskipun saat pemutaran video diperbesar, gambar yang dihasilkan jelas untuk mendeskripsikan perilaku perorangan.

\section{Analisis}

Dalam menganalis data pengamatan yang telah terkumpul baik itu berupa rekaman video maupun data yang tetulis, pengamat menarasikan semua data tersebut. Maksudnya, data yang awalnya berupa video akan ditulis dalam bentuk narasi. Begitu pula data yang tertulis. Hal ini bertujuan untuk mendapatkan konseptualisasi dari pengamatan yang telah dilakukan.

Langkah selanjutnya, peneliti melakukan reduksi terhadap narasi tersebut. Proses reduksi data adalah proses mengurangi data yang saat narasi sebetulnya tidak diperlukan serta memfokuskan data kasar pada catatan lapangan. Salah satu cara untuk mereduksi data adalah dengan coding (pengkodean).

Pengkodean akan dilakukan sebanyak dua kali. Pertama, akan dilakukan pengkodean dari seluruh data pengamatan. Berikutnya, pengkodean dilakukan terhadap data yang mempunyai hubungan dengan pertanyaan penelitian. 
Pengkodean adalah serangkaian proses data analisis untuk mendapatkan konseptualisasi dan mengidentifikasi beberapa jenis data seperti transkrip, catatan lapangan, arsip, laporan, artikel surat kabar dan seni. Proses pengkodean mengarah pada langkah-langkah peneliti untuk mengidentifikasi, menyusun, dan mensistematiskan ide, konsep maupun kategori dari data-data yang tidak tercover. (Lofland \& Lofland: 1995)

\section{Temuan}

Penelitian ini ingin mengetahui bagaimana dampak penempatan videotron terhadap perilaku berlalu lintas khususnya pengendara motor dan orang yang diboncengnya. Sehingga, untuk menjawab pertanyaan ini dilakukan pengamatan terhadap perilaku para pengendara berlalu lintas beserta orang yang diboncengnya terhadap videotron yang ada di perempatan mall Galeria. Berikut adalah poin-poin temuan dan pembahasannya pada poin yang sama:

\section{Denah Perempatan}

Denah perempatan adalah gambaran mengenai hal-hal yang ada di sekitaran perempatan. Termasuk arah dan tata letak rambu apill. Berikut adalah gambaran dari denah perempatan Mall Galeria:

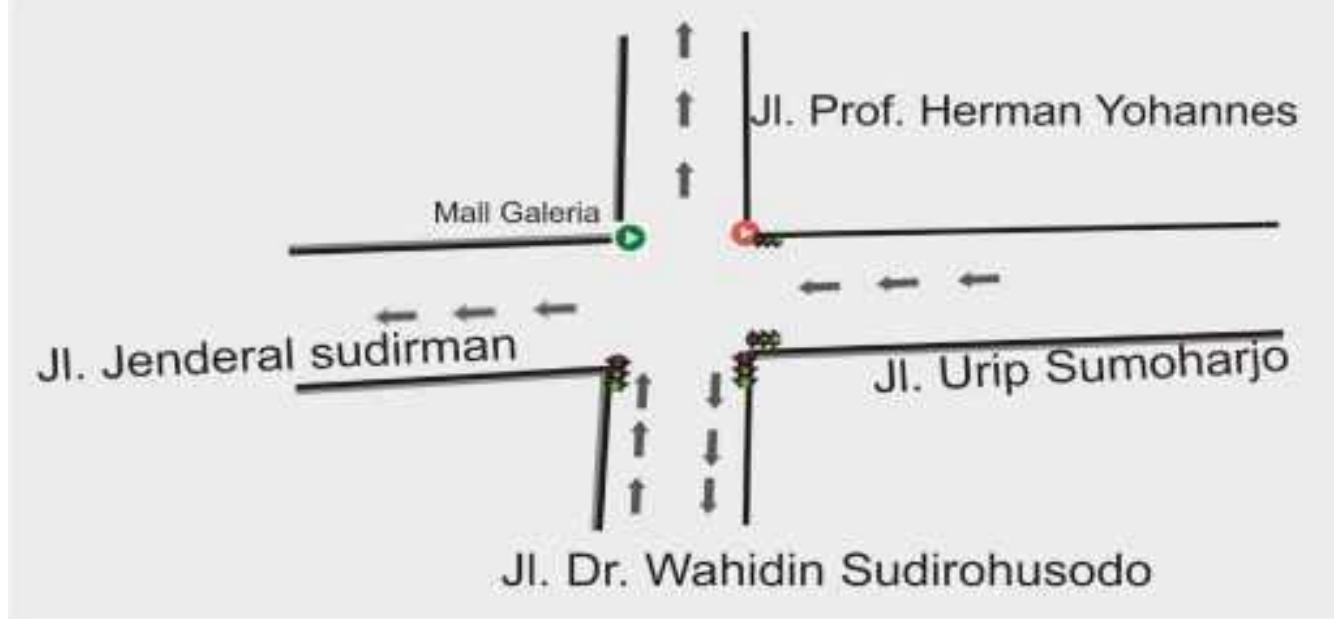

\section{Keterangan :}

- Videotron melekat pada mall Galeria

- Videotron yang terpasang di seberang mall Galeria

Arah utara perempatan ini merupakan Jalan Prof. Herman Yohannes, jalan ini mengarah pada kampus UGM (Universitas Gadjah Mada) dan UNY (Universitas Negeri Yogyakarta). Jalan ini merupakan jalan satu arah yang dapat dilewati oleh pengendara dari arah selatan maupun timur. Namun, tidak bisa dilewati oleh pengendara dari arah barat, karena jalur barat merupakan jalur satu arah, yaitu Jalan Jenderal Sudirman. Jalan 
Jenderal Sudirman sendiri merupakan jalan satu arah dari perempatan (baik itu dari arah timur maupun selatan).

Sebelah selatan perempatan, merupakan jalan Dr. Wahidin Sudirohusodo. Jalan ini merupakan satu-satunya jalan dua arah yang ada pada perempatan mall Galleria. Salah satu arah dari jalan ini dilewati melalui kampus UKDW (Universitas Kristen Duta Wacana). Lainnya adalah arah dari jalur jalan uripsumoharjo. Arah dari Jalan Urip Sumoharjo hanya dapat dilewati satu arah saja menuju ke mall galeria atau menuju ke Jalan Profesor Yohannes atau ke arah UKDW. Sebelah timur dari perempatan merupakan jalan satu arah. Arah satu arah hanya berlaku dari arah Jalan Urip Sumoharjo menuju ke perempatan Mall Galeria.

\section{Atensi terhadap Videotron}

Terdapat dua videotron yang terpasang pada perempatan Mall Galeria. Videotron pertama terletak menempel pada dinding Mall Galeria. Ukuran videotron ini adalah 7,5 m x $4 \mathrm{~m}$. Videotron kedua terletak di seberang atau timur mall galeria dan terpampang oleh tiang. Ukuran videotron ini adalah $5 \mathrm{~m}$ x $3 \mathrm{~m}$. Videotron pertama mempunyai ukuran yang lebih luas dibandingkan videotron yang kedua. Begitu juga dengan tingginya, videotron pertama lebih tinggi dibandingkan videotron pertama.

Beberapa pengendara (orang yang membonceng) mengarahkan pandangan mereka sekilas pada videotron yang ukurannya lebih besar saat mereka berhenti di perempatan. Adapula seorang perempuan yang dibonceng dan duduk menghadap pengendara, ia merespon keberadaan videotron dengan melihat videotron tersebut. Dalam waktu yang berbeda, terdapat dua orang yang merespon videotron hingga mereka mendongakkan kepala mereka setelah lampu hijau menyala, hanya untuk melihat ke arah videotron tersebut. Ketika peneliti mencoba untuk mengukur waktu 'sekilas' dari orangorang yang memandang videotron tersebut. Ditemukan bahwa waktu sekilas itu berkisar antara 3 detik. Bisa kurang maupun lebih. Temuan lain adalah respon para pengendara dari arah Jalan Dr. Wahidin Sudirohusodo terhadap videotron yang berada di sebelah timur perempatan hanya memandang sekilas saja. Dan ukuran sekilasnya-pun sama, kurang lebih tiga detik. Sedangkan para pengendara dari arah jalan Urip Sumoharjo, lebih sering memandang sekilas ke arah videotron yang yang ukurannya lebih besar.

\section{Rambu Apill (Alat Pemberi Isyarat Lalu Lintas)}

Pada arah Jalan Dr. Wahidin Sudirohusodo terdapat dua rambu apill. Rambu apill pertama terdapat di sebelah kiri pemberhentian. Tingginya sekitar 9 meter yang kemudian diberi nama rambu $9 \mathrm{~m}$ (penjelasan lebih lanjut pada poin 4). Sedangkan rambu apill yang kedua, lebih rendah daripada rambu yang pertama, tingginya berkisar 5 meter (penjelasan lebih lanjut pada poin 5). Di sisi lain, sebelah selatan perempatan ini terdapat rambu apill yang tingginya sekitar 5 meter. Sedangkan sebelah kanan/ utara dari perempatan terdapat rambu yang lebih tinggi daripada yang berada di sebelah selatan. Tingginya berkisar antara 9 meter. 


\section{Atensi terhadap Rambu 9 m}

Respon pengendara terhadap rambu apill berukuran $9 \mathrm{~m}$ dapat dilihat dari pengendara yang mendongkrakan kepalanya ke atas dan pandangannya mengarah pada rambu apill. Peneliti menemukan pula seorang pengendara yang membonceng seseorang di belakangnya, mereka berdua memandangi rambu tersebut sambil berbincang-bincang. Hingga lampu hijau menyala, mereka langsung melaju. Bahkan, ada saat dimana seseorang membunyikan klakson untuk tujuan tertentu, seperti memberi tanda pada pengendara di depannya untuk melaju karena lampu sudah menyala hijau. Atau, memberi tanda kepada pengendara di depannya yang sedang berhenti di jalur belok kiri untuk berpindah tempat karena dia akan belok kiri. Membunyikan klakson seperti ini mempunyai dampak terhadap pengendara lain. Kebanyakan dari pengendara itu melihat, melirik, memandang bahkan ada yang mendongkkan kepalanya juga, ketika bunyi klakson terdengar. Di situasi yang berbeda, ada seorang pengendara yang dari awal saat dia berhenti karena lampu berwarna merah hingga lampu berwarna hijau, ia tetap memandangi rambu tersebut, tanpa melihat ke arah lain.

\section{Atensi terhadap Rambu 5 meter}

Respon yang hampir sama terhadap rambu apill 9 meter, ditemukan pula pada rambu apill berukuran 5 meter. Begitu pula ketika ada situasi dimana seseorang membunyikan klakson dengan tujuan tertentu. Namun, secara keseluruhan dari data yang ditemukan, para pengendara dan orang yang dibonceng mempunyai kecenderungan yang tinggi untuk melihat rambu aphil dengan tinggi 5 meter, hanya saat lampu merah menyala.

\section{Atensi terhadap Iklan Luar Ruangan Lainnya}

Hal lain yang mungkin para pengendara motor dan yang dibonceng lalukan adalah melihat ke berbagai iklan yang menjadi perhatian mereka. Iklan tersebut antara lain adalah billboard dan spanduk.

\section{Atensi terhadap Hal Lainnya}

Berbagai macam hal yang dapat dilihat dan ada di perempatan itu, memungkinkan untuk dapat menjadi gangguan secara visual terhadap para pengguna lalu lintas. Berbagai macam data yang didapatkan tersebut antara lain kehadiran peneliti yang merekam menggunakan handycam dan terpasang di tripot, arah pandangan terhadap benda yang bergerak termasuk terhadap gerakan pengendara lain, kebanyakan pengendara motor yang berperan sebagai pembonceng atau supir motor mempunyai kecenderungan untuk menoleh ke arah kanan pada waktu sesaat setelah mereka berhenti di perempatan, serta cukup banyak dari mereka yang selalu memegang HP dan berinteraksi dengan alat tersebut (telepon maupun menggerakkan jarinya terhadap alat tersebut), dan setiap pengendara yang berada pada baris terdepan saat lampu merah lebih condong melihat ke arah depan.

Berdasarkan denah lokasi perempatan mall galeria ini, pemasangan iklan videotron dengan sengaja di tempatkan pada titik dimana dapat dilihat oleh pengendara yang sedang berhenti saat lampu merah menyala. Hal ini dapat terbukti dari kemiringan 
peletakkan videotron di sebelah barat Mall galeria. Namun, hal ini berbeda dengan penempatan videotron pada sebelah barat Mall Galeria. Videotron tersebut dipasang lurus menghadap selatan dan hanya pengendara dari arah kampus UKDW dan jalan uripsumarjo yang hendak melaju lurus saja yang bisa melihatnya. Sedangkan, dari arah Jalan Urip Sumoharjo ke arah utara, tidak akan bisa meihatnya, karena tertutup oleh pohon yang ada di situ.

Pada dasarnya, setiap iklan termasuk iklan luar ruangan dan termasuk pula videotron adalah iklan yang 'memaksa' orang untuk meresponnya. Sehingga, untuk kasus iklan luar ruangan, respon yang sering diberikan oleh pengendara adalah dalam bentuk attention (atensi atau perhatian). Perhatian ini selalu berkaitan dengan penglihatan visual, antara lain melihat sekilas, memandang, melirik dan menonton. Hal ini sesuai dengan pendapat dari Kapitaniak el all (2015) yang menyatakan bahwa saat seseorang berkendara pengelihatan visual mereka terpengaruh dan terdistorsi oleh benda-benda yang ada di sekitar mereka, dalam kasus ini termasuk videotron.

Pada kasus penempatan videotron pada mall galeria, respon yang diberikan oleh para pengguna lalu lintas baik itu pengendara maupun yang dibonceng mempunyai level. Level ini dapat dilihat dari durasi dan perilaku seseorang ketika ia melihat ke arah objek. Level pertama adalah level melihat sekilas, artinya orang tersebut hanya memiliki ketertarikan sesaat kepada videotron tersebut. Biasanya, setelah memandang sekilas, ia akan menolehkan kepalanya ke arah lain. Dan level ini menempati urutan terbanyak saat pengamatan berlangsung.

Level berikutnya adalah level memandang. Biasanya, para pengendara memandang ke depan sambil menunggu lampu merah menjadi hijau. Justru, kadar mereka melihat rambu apill lebih sedikit dibandingkan dengan melihat videotron. Level yang paling sedikit adalah menonton. Dalam pengamatan ini, hanya ditemukan dua orang yang menonton videotron meskipun mereka telah melaju melewati rambu apill. Dalam dunia periklanan, seseorang yang menonton sebuah iklan memiliki arti bahwa ia tertarik terhadap iklan tersebut atau dia sedang dalam keadaan membutuhkan/mencari sesuatu yang sedang di iklankan tersebut. Level - level ini yang akan menjadi pembanding untuk melihat videotron yang ditempatkan pada sebelah timur mall galeria. Dan hasilnya hampir sama.

Sebagai pembanding, level ini akan diterapkan pada perempatan Malioboro dimana terdapat sebuah videotron yang dapat dilihat oleh para pengendara dalam waktu lebih dari 60 detik (waktu yang cukup lama). Dari segi ukuran, videotron ini lebih kecil dibandingkan dengan videotron berukuran 5 m x 3 m yang ada di Mall Galeria.

Hasil yang diperoleh pada pengamatan tersebut cukup mengejutkan. Meskipun waktu rambu merah 70 detik hingga 100 detik , artinya lebih lama dibandingkan dengan perempatan Galleria, namun attention (perhatian) yang diberikan oleh pengendara tersebut tidak cukup banyak dibandingkan dengan perempatan pada Galleria. Penemuan tersebut terbukti dari kegiatan yang dilakukan para pengendara di perempatan tersebut antara lain adalah merokok, bermain HP, mengaca, membetulkan posisi duduknya, dan lain sebagainya.

Perbedaan atensi tersebut mungkin dapat dipengaruhi oleh jarak pandang dan kemiringan videotron yang berbeda. Secara sekilas di perempatan Malioboro, jarak antara 
videotron dengan rambu lalu lintas di seberangnya lebih jauh dibandingkan dengan yang ada di perempatan Mall Galeria. Namun, peneliti belum mengukurnya secara pasti.

Peneliti mengakui kelemahan dalam penelitian ini terletak pada cara pengumpulan data. Untuk melihat seberapa jauh dampak dalam hal ini adalah atensi dari para pengguna jalan, mungkin dapat dilakukan dengan eye-tracking atau penelitian experimental menggunakan kamera yang di pasang pada kepala pengendara. Hal ini adalah cara peneliti sebelumnya mencoba menemukan jawaban terhadap iklan billboard dan perilaku berkendara. Namun, kelebihan dari model pengamatan ini adalah, peneliti tidak hanya terfokus untuk menemukan atensi, melainkan juga dapat menemukan penyebab mengapa tidak semua pengendara merespon dan memberikan atensi terhadap videotron. Sehingga penelitian ini melengkapi penelitian yang sebelumnya telah dilakukan oleh Duchwoski (2002), Kapitaniak et. al (2015), Rustan (2009), Taylor et. al (2006), dan Kasali (1992).

\section{Kesimpulan}

Setelah melalui prosedur pengamatan dengan metode terlibat dan tidak terlibat untuk menjawab pertanyaan bagaimanakah dampak penempatan videotron pada perilaku berlalu lintas pengendara sepeda motor dan yang diboncengnya, peneliti melakukan analisis menggunakan metode pengkodean sehingga ditemukan tujuh kode meliputi denah perempatan, atensi terhadap videotron, atensi terhadap rambu apill, atensi terhadap rambu apill setinggi 9 meter, atensi terhadap rambu apill setinggi 5 meter, atensi terhadap iklan luar ruangan, atensi terhadap hal lain. Atensi dalam kasus ini dibagi menjadi tiga : melihat sekilas, memandang, dan menonton. Melihat sekilas menjadi hal yang paling sering pengendara lakukan terhadap videotron. Hal ini dapat disebabkan karena banyaknya hal yang juga dapat menjadi stimuli untuk atensi dari pengendara tersebut antara lain objek yang bergerak, iklan outdoor lainnya, rambu apill tentunya dan kegiatan individu itu sendiri saat lampu merah berlangsung.

Peneliti mengakui kelemahan dalam penelitian ini terletak pada cara pengumpulan data. Namun, kelebihan dari model pengamatan ini adalah, peneliti tidak hanya terfokus untuk menemukan atensi, melainkan juga dapat menemukan penyebab mengapa tidak semua pengendara merespon dan memberikan atensi terhadap videotron.

\section{Kepustakaan}

all, K. e. 2015. Application of eye-tecking in drivers testing: a review research. International Journal.

Duchowski AT . 2002. A Breadht-first survey of eye tracking applications. Behaviour Res Methods Instrument Computer.

Kapitaniak Bronislaw, Walczak Marta, Kosobudzki Marcin, Jozwiak Zbigniew, Bortkiewicz Alicja. 2015. Application of Eye Tracking in Drivers Testing . International Journal of Occupational Medicine and Enviromental health . 941 - 954 
Kasali, R. 1992. Manajemen Periklanan dan konsep dan Aplikasinya di Indonesia. Jakarta: Pustaka Utama Graffiti.

Loftland J anf L.H Loftland. 1995. Analyzing Social Settings: a guide to qualitative observation and analysis. Belmont, CA, Wadsworth Publishing Company.

Lorentz, W. 2002. The Impact of Modern Traffic and traditional Life on Informal Traffic Rules. The Social impacts of new roads in Southeast Asia, 158.

Morissan. 2014. Periklanan Komunikasi Pemasaran Terpadu. Jakarta: Kencana.

Rustan, S. 2009. Periklanan. Jakarta: Gramedia Pustaka Utama.

Susanto, M. 2011. Diksi Rupa. Yogyakarta: DictiArt Lab.

Shinar, D. 2007. Traffic Safety and Human Behaviour.Amsterdam: Elsevier.

Taylor C R , Franke G R , Bang Hae-Kyong. 2006. Use and Effectiveness of Billboards Perspectives from Selective-perception Theory and Retail Garvity Models. Journal of Advertising. p. 21 